\title{
Dissemination mapping through spatial distribution pattern of day-old local chicken in West Java, Indonesia
}

\author{
Fatwi Zandos ${ }^{1}$, Mohammad Ikhsan Shiddieqy ${ }^{2}$, and $K$. Komarudin ${ }^{3}$ \\ ${ }^{1}$ Fisheries and Livestock Service, Government of Bogor Regency, Cibinong, Bogor, Indonesia \\ ${ }^{2}$ Indonesian Center for Animal Research and Development, Bogor, Indonesia \\ ${ }^{3}$ Indonesian Research Institute for Animal Production, Ciawi, Indonesia
}

\begin{abstract}
Local chicken has several potential functions in Indonesia, especially as an alternative source of food. Over the last decade, local chicken farms have been growing rapidly to supply the increasing demand of local chicken meat. The government continues to disseminate and spread high-quality local chicken breeds, including KUB Chicken. This study aims to analyse the spatial distribution of day-old local chicken (DOC) as part of dissemination program in Bogor Regency, West Java, Indonesia. The method of this study was descriptive with field observation to collect primary data. Secondary data was used as comparison. The amount of DOC was calculated from three years dissemination program $(2018,2019$ and 2020). The results showed 80,120 DOC were distributed to 204 farmers groups in 35 subdistricts in Bogor in the last three years. Cibungbulang Subdistrict has received the most DOC and Cisarua Subdistrict has received the least the DOC with the number of 8,846 DOC and 352 DOC, respectively. This study shows that the spatial distribution of DOC was not spread equally. This study suggests the enhancement of distribution of DOC, especially to the subdistricts in central part of Bogor and has a low population of local chicken.
\end{abstract}

\section{Introduction}

Indonesia has a variety of genetic sources for local chickens spread throughout the region [1]. There are 31 native chicken breeds in Indonesia [2, 3]. It shows that Indonesia has a wealth of genetic resources of native and local chicken with abundant genetic diversity [1]. Animal genetic resources such as indigenous chickens are part of biodiversity [4]. Local indigenous chickens in Indonesia differ from those in Asia and other countries in the world. Therefore, Indonesia is one of the major chicken domestication centres in the world, besides China and India [3].

Local chicken plays an important role in meeting the needs of animal protein source for more than 270 million Indonesians. Local chickens are highly adaptable and resistant to a variety of diseases that commonly affect layer and broiler chickens [5]. It contributes greatly to the rural economy because local chicken mostly kept by smallholder farmers $[1,2]$. Local chicken represents one of the few opportunities for saving, investment and security against risk [2]. 
National local chicken meat production has continued to increase in recent years [6]. This increase in production is in line with the national demand for local chicken meat which shows an increasing trend. This trend is predicted to continue to increase along with the increase in population and the increase in the purchasing power of the Indonesian people [6].

Indigenous chickens in Indonesia are often called ayam bukan ras (buras) or non-breed chickens and ayam kampung or village chickens [3]. Sentul, Pelung and Kedu are some major local chicken breeds in Indonesia. Universities and research institutions are doing genetic improvement of local chicken. Since 1998, Indonesian Research Institute for Animal Production (IRIAP), a subsidiary of Indonesian Agency for Agricultural Research and Development (IAARD), has selected kampung chicken for egg production [7]. The base population of local chicken which was obtained from several locations in West Java, was selected for six generations with selection criteria of 24 weeks egg production and selection intensity of $50 \%$. The chicken was eventually named as KUB (IAARD's Superior Local Chicken/Ayam Kampung Unggul Balitbangtan) G6 chicken [7].

Native and local chickens contribute greatly to the rural economy, but their production is still limited [1]. Despite its low productivity, native chicken production is very important for rural communities. However, they face challenges how to increase the productivity of their population, which can benefit them financially and increase food security and reach potential market [1].

Increasing the output of local chicken meat and eggs can be accomplished effectively through breeding programs (selection and crossing). [1]. In addition, traditional feeding management can help to improve the quality of local chickens. The supply of selected local chicken in response to market demand is still limited. [1]. The allocation of day-old local chicken (DOC) to farmers as an in-kind input in dissemination program is important to increase the population of local chicken and farmers economy. However, the spread of the DOC allocation is not known yet. The objective of the study was to analyse the spatial distribution of day-old local chicken (DOC) as part of dissemination program in Bogor, West Java.

\section{Material and methods}

This study was conducted in Bogor Regency, West Java, Indonesia. Bogor is one of 16 regencies in West Java Province (Fig. 1). It has total area of $2,986.20 \mathrm{~km}^{2}$ and has 40 subdistricts. Fisheries and Livestock Service of Bogor has a program to allocate DOC of KUB breed as an aid and dissemination program. The DOC was distributed to farmer groups. Farmers raise the DOC for saving and consumption. They received regular Technical Guidance meeting to increase their knowledge and experience in chicken farming.

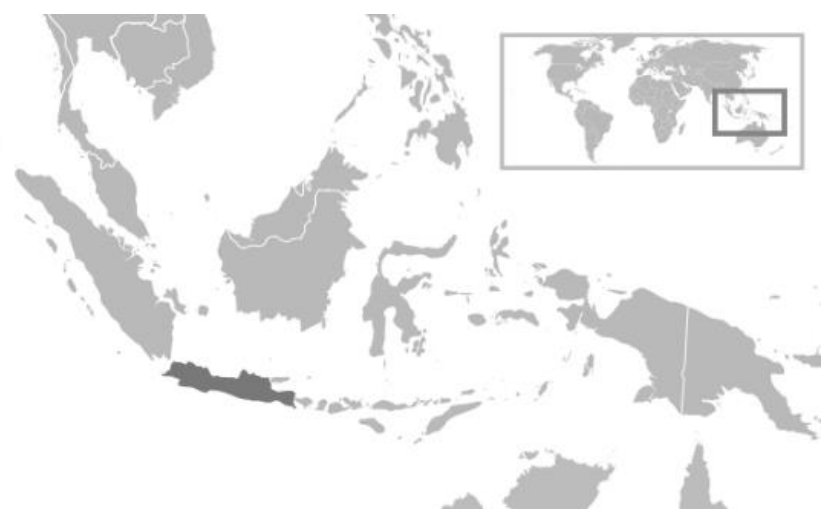




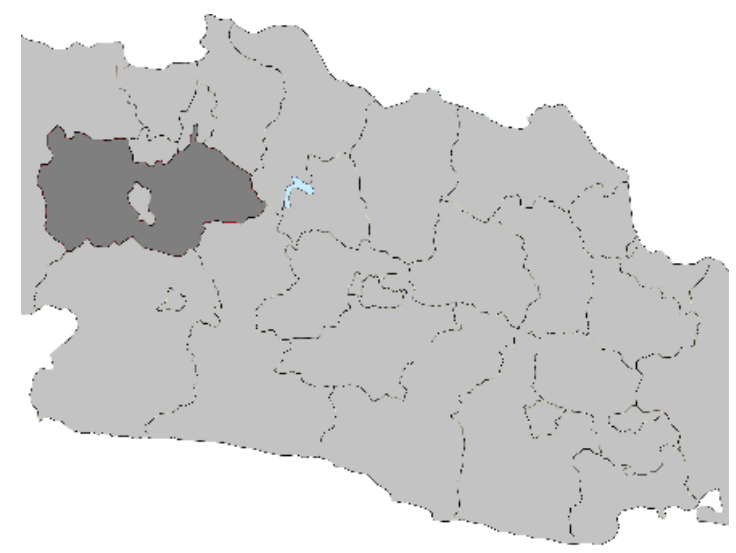

Fig. 1. The position of Indonesia on a world map. Java is shown on darker color (upper). Bogor Regency in West Java Province as the area of research is shown in a darker color (lower). The brighter area in the middle of Bogor Regency is Bogor Municipality which was not take into account in this research

The method of this study was descriptive with field observation to collect primary data. Secondary data was used as comparison. The amount of distributed DOC was calculated from three years dissemination program $(2018,2019$ and 2020). Field observation was conducted in Rumpin Subdistrict, Bogor on March 2020. This observation was carried out in conjunction with a Technical Guidance meeting for beneficiary farmers. Field observation aimed to evaluate the progress of chicken farming in several farmer groups who received DOC distribution in previous year. The farmers also able to discuss some difficulties and constrains with researchers and extension workers during a Technical Guidance meeting.

\section{Results and discussion}

The results showed that $84,337 \mathrm{DOC}(80,120 \mathrm{DOC}$ if mortality assumed 5\%) were distributed to 204 farmers groups in 35 subdistricts in Bogor in the last three years. Each subdistrict received 2.003 DOC in average. Mortality was taken into account because it represents the amount of DOC that survive to grow until adult phase. in the other words, the distribution of 84,337 DOC was estimated to become 80,120 adult local chicken in the next 2-3 months. Meanwhile, the total existing population of adult local chicken in Bogor was 1,837,219 heads and the average population in subdistrict was $45,930.48$ heads [8]. The total DOC distribution was only $4.36 \%$ from total existing population of local chicken in Bogor. Details distribution in 40 subdistricts were shown in Table 1. 
Table 1. The distribution of DOC calculated from three years dissemination program in subdistricts of Bogor

\begin{tabular}{|c|c|c|c|c|c|c|c|}
\hline \multirow[b]{2}{*}{ No } & \multirow[b]{2}{*}{ Subdistricts } & \multicolumn{3}{|c|}{ Years (DOC) } & \multirow{2}{*}{$\begin{array}{c}\text { Total } \\
\text { distributed } \\
(\mathrm{DOC})^{1}\end{array}$} & \multirow{2}{*}{$\begin{array}{c}\text { Total } \\
\text { existing } \\
\text { population } \\
\text { (head) }\end{array}$} & \multirow{2}{*}{$\begin{array}{c}\text { Percentage } \\
\text { of total } \\
\text { distributed } \\
\operatorname{DOC}^{3}(\%)\end{array}$} \\
\hline & & 2018 & 2019 & 2020 & & & \\
\hline 1 & Babakan Madang & 377 & 400 & 400 & 1,118 & 15,550 & 7.19 \\
\hline 2 & Bojonggede & 0 & 0 & 500 & 475 & 1,274 & 37.28 \\
\hline 3 & Caringin & 0 & 0 & 400 & 380 & 37,394 & 1.02 \\
\hline 4 & Cariu & 0 & 775 & 0 & 736 & 82,000 & 0.90 \\
\hline 5 & Ciampea & 230 & 2,140 & 1,080 & 3,278 & 32,789 & 10.00 \\
\hline 6 & Ciawi & 0 & 0 & 0 & 0 & 16,575 & 0.00 \\
\hline 7 & Cibinong & 1,007 & 2,750 & 1,302 & 4,806 & 8,059 & 59.64 \\
\hline 8 & Cibungbulang & 1,520 & 2,980 & 4,812 & 8,846 & 5,254 & 168.37 \\
\hline 9 & Cigombong & 400 & 706 & & 1,051 & 43,750 & 2.40 \\
\hline 10 & Cigudeg & 652 & 450 & 2,546 & 3,466 & 41,668 & 8.32 \\
\hline 11 & Cijeruk & 0 & 0 & 0 & 0 & 29,445 & 0.00 \\
\hline 12 & Cileungsi & 0 & 0 & 0 & 0 & 16,296 & 0.00 \\
\hline 13 & Ciomas & 0 & 0 & 800 & 760 & 17,663 & 4.30 \\
\hline 14 & Cisarua & 0 & 370 & 0 & 352 & 12,019 & 2.92 \\
\hline 15 & Ciseeng & 1,573 & 0 & 400 & 1,874 & 24,487 & 7.65 \\
\hline 16 & Citeureup & 420 & 0 & 400 & 779 & 27,157 & 2.87 \\
\hline 17 & Dramaga & 911 & 3,537 & 1,190 & 5,356 & 25,765 & 20.79 \\
\hline 18 & Gunung Putri & 0 & 0 & 1,080 & 1,026 & 9,536 & 10.76 \\
\hline 19 & Gunungsindur & 521 & 353 & 0 & 830 & 8,600 & 9.65 \\
\hline 20 & Jasinga & 881 & 335 & 1,760 & 2,827 & 60,913 & 4.64 \\
\hline 21 & Jonggol & 1,466 & 1,308 & 400 & 3,015 & 244,172 & 1.23 \\
\hline 22 & Kemang & 0 & 800 & 428 & 1,167 & 8,966 & 13.01 \\
\hline 23 & Klapa Nunggal & 0 & 1,675 & 0 & 1,591 & 16,161 & 9.85 \\
\hline 24 & Leuwiliang & 0 & 1,582 & 400 & 1,883 & 65,166 & 2.89 \\
\hline 25 & Leuwisadeng & 2,551 & 2,155 & 3,200 & 7,511 & 39,586 & 18.97 \\
\hline 26 & Megamendung & 0 & 0 & 0 & 0 & 106,299 & 0.00 \\
\hline 27 & Nanggung & 0 & 370 & 0 & 352 & 36,419 & 0.97 \\
\hline 28 & Pamijahan & 2,048 & 2,350 & 3585 & 7,584 & 57,235 & 13.25 \\
\hline 29 & Parung & 0 & 0 & 396 & 376 & 478,733 & 0.08 \\
\hline 30 & Parung Panjang & 0 & 0 & 1,170 & 1,112 & 36,419 & 3.05 \\
\hline 31 & Rancabungur & 1,020 & 0 & 1,195 & 2,104 & 26,544 & 7.93 \\
\hline 32 & Rumpin & 308 & 2,532 & 1,610 & 4,228 & 44,388 & 9.52 \\
\hline 33 & Sukajaya & 0 & 0 & 455 & 432 & 36,419 & 1.19 \\
\hline 34 & Sukamakmur & 0 & 815 & 0 & 774 & 1,336 & 57.95 \\
\hline 35 & Sukaraja & 0 & 0 & 0 & 0 & 28,465 & 0.00 \\
\hline 36 & Tajur Halang & 0 & 850 & 1,235 & 1,981 & 6,001 & 33.01 \\
\hline 37 & Tamansari & 0 & 407 & 0 & 387 & 27,572 & 1.40 \\
\hline 38 & Tanjungsari & 0 & 800 & 0 & 760 & 1,570 & 48.41 \\
\hline 39 & Tenjo & 0 & 0 & 2,124 & 2,018 & 34,915 & 5.78 \\
\hline 40 & Tenjolaya & 519 & 1,247 & 3,378 & 4,887 & 24,659 & 19.82 \\
\hline & Total & 16,404 & 31,687 & 36,246 & 80,120 & $1,837,219$ & 4.36 \\
\hline
\end{tabular}

${ }^{1}$ Total distributed DOC was corrected with $5 \%$ mortality ( $95 \%$ of DOC assumed to grow until adult)

${ }^{2}$ Adult local chicken [8]

${ }^{3}$ Total distributed DOC compare to total existing adult local chicken

For three years dissemination program, there were 5 subdistricts that did not received DOC distribution, namely Ciawi, Cijeruk, Cileungsi, Megamendung and Sukaraja. Cibungbulang has received the most DOC and Cisarua Subdistrict has received the least the 
DOC with the number of 8,846 DOC and 352 DOC, respectively. With regards to the existing local chicken, distributed DOC in Cibungbulang was $168.37 \%$ of the existing local chicken (5,254 heads). It means the dissemination of DOC in Cibungbulang was projected to increase the total population of adult local chicken. The existing local chicken population in Cibungbulang was considerably low compare to the average population in subdistrict. The lowest existing population was recorded in Bojonggede (1,274 heads) which received 475 DOC (37.28\% of total existing).

In 2018 , total distributed DOC was 16,404 heads, which is only half compare to total distributed DOC in the following years. There were only 17 subdistricts out of 40 subdistricts that received DOC dissemination. The low distributed DOC population and the low range of distribution were probably caused by program which still on the initiation phase. Before the dissemination was conducted, prospective beneficiary farmers were validated. It caused the administration works were dominated in first year of the program.

The highest number of distributed DOC was recorded in Leuwisadeng and the lowest in Ciampea, with the number of 2,551 and 230 DOC, respectively (Fig. 2). With regards to the spatial observation, distribution of DOC was dominated in central and western part of Bogor (Fig. 3). The subdistricts in western part, especially Jasinga, Cigudeg, and Rumpin, were known as a center of chicken farming. The population of local chicken in western part subdistricts was above subdistrict average. It means the western part subdistricts were a center of chicken farming with abundant feed sources and skilled farmers.

The distribution of DOC to the western part in the initial phase of the program was possibly aims to maintain the success rate in raising distributed DOC. It was assumed that beneficiary farmers in the area have indigenous knowledge of chicken farming. This knowledge refers to the skills and experience passed from generations to generations [9]. However, these farmers are still an object of empowerment that enable them to perform certain tasks that can lead to their development, so they are keen to change and are better informed to take decisions [9].

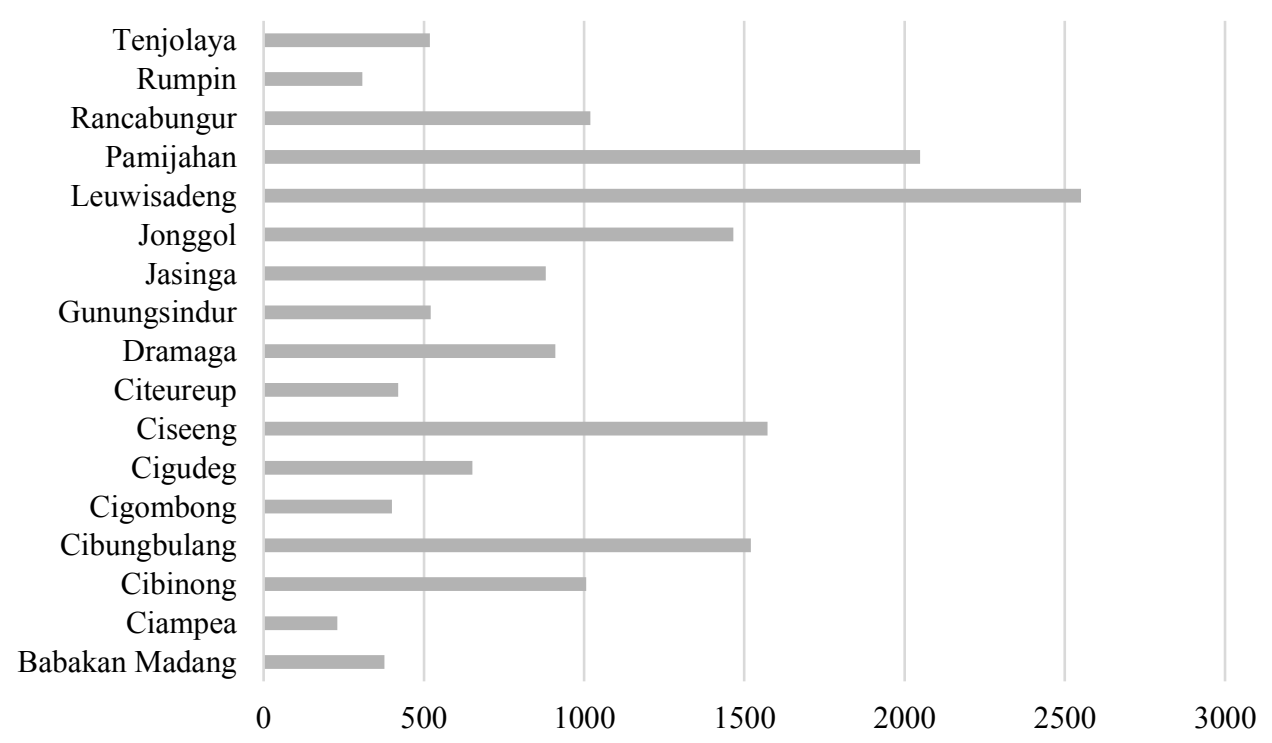

Fig. 2. The amount of distributed DOC in subdistricts of Bogor in 2018 


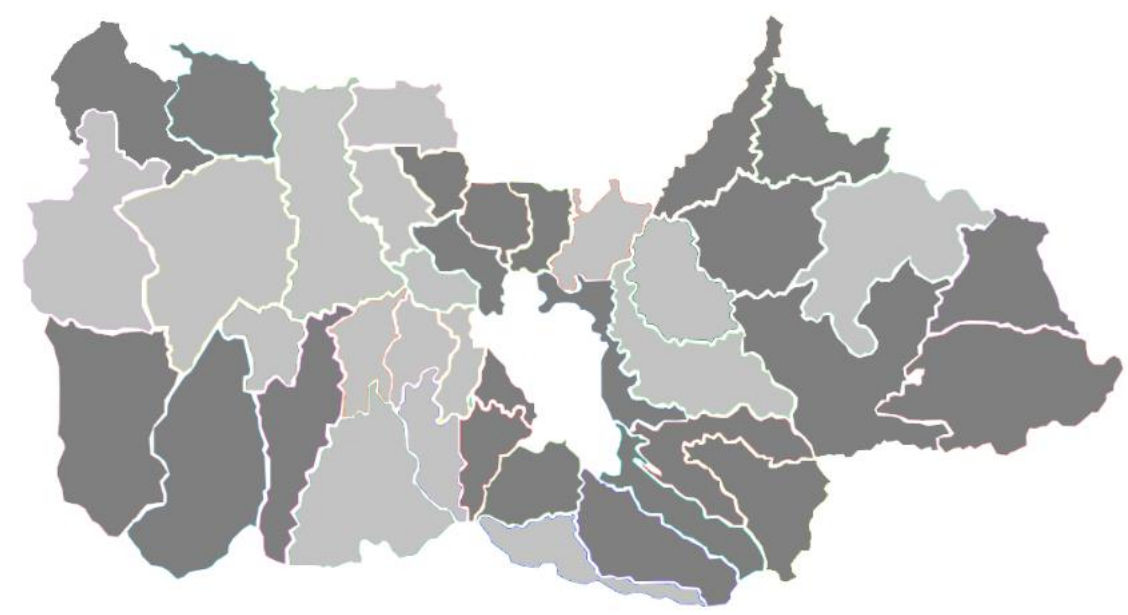

Fig. 3. The spatial distribution of DOC in 40 subdistricts of Bogor in 2018. Darker color represent the subdistricts that did not received DOC allocation

In 2019, total distributed DOC was 31,687 heads, which was double from total distributed DOC in the previous years. The participated subdistricts in DOC distribution also increase. There were 24 subdistricts that received DOC dissemination (Fig. 4). It is more than half of total 40 subdistricts in Bogor. The increase in distributed DOC population and the increase in range of distribution were probably caused by improvement in program infrastructure, planning and more parties involved. Farmers, rural leaders and networks, community groups, and other development organizations must all be involved, which necessitates innovative solutions and ongoing efforts [10].

The highest number of distributed DOC was recorded in Dramaga and the lowest in Jasinga, with the number of 3,537 and 230 DOC, respectively (Fig. 4). With regards to the spatial observation, distribution of DOC was dominated in western and eastern part of Bogor (Fig. 5). The subdistricts in eastern part, especially Sukamakmur, Jonggol and Cariu, were also known as a center of chicken farming. They have abundant feed sources and skilled farmers.

Eastern part of Bogor has a large area of rice field which potential for local chicken feed source. Rice bran is an energy and protein rich ingredient used in poultry feeding [11]. Rice bran is a powdery fine, fluffy material that consists seeds or kernels, in addition to particles of pericarp, seed coat, aleurone, germ and fine starchy endosperm [11]. In the eastern part of Bogor, there is a potential for the development of local chicken integration with rice fields and fish culture. In some countries, this integration showed a significant increase in nutritional status and livelihoods of participating farmers [12]. Therefore, the decision to include the eastern part of Bogor as dissemination area was likely to maximize the potential of rice field as a feed source in local chicken farming. 


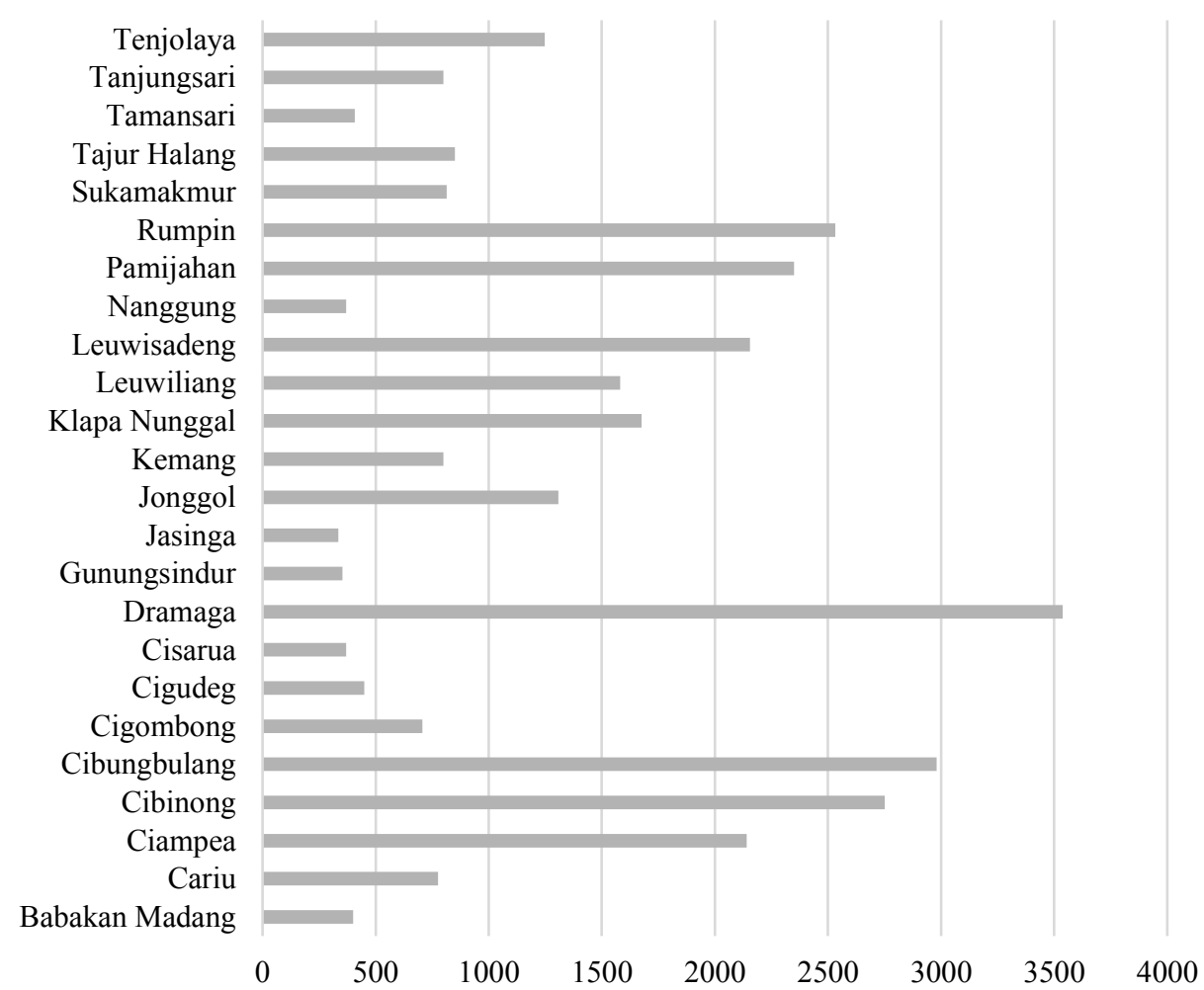

Fig. 4. The amount of distributed DOC in subdistricts of Bogor in 2019

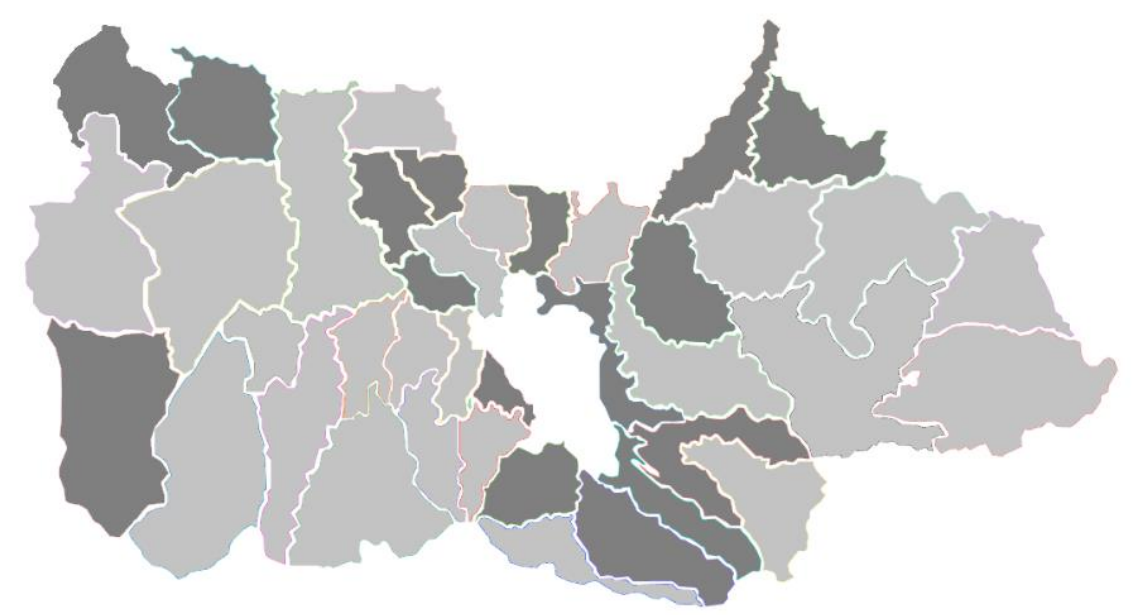

Fig. 5. The spatial distribution of DOC in 40 subdistricts of Bogor in 2019. Darker color represent the subdistricts that did not received DOC allocation 
In 2020, total distributed DOC was 36,246 heads, which is slightly increase from total distributed DOC in the previous years. The participated subdistricts in DOC distribution also increase. There were 26 subdistricts that received DOC dissemination. It is more than half of total 40 subdistricts in Bogor. The highest number of distributed DOC was recorded in Cibungbulang and the lowest in Parung, with the number of 4,812 and 396 DOC, respectively (Fig. 6). With regards to the spatial observation, distribution of DOC was dominated in western part of Bogor (Fig. 7).

Another important aspect to highlight in 2020 distribution was the inclusion of industrial subdistricts, such as Gunung Putri, Citeureup and Cibinong. These subdistricts host numerous manufacturing industries, automotive plants and the other factories. However, these subdistricts also have a high existing population of local chicken. It means that the area has supporting factors for chicken farming. It also shows that rural farmers were still exist in the industrial area. Rural farmers refer to farmers living in the rural areas, most of them have low level of education, their major occupation is subsistence farming and they are generally characterized by poor farming practices [9]. This was a challenge to provide assistance for farmers following the distribution of DOC. Extension planners face the difficult challenges of being creative in their programme development efforts and responsive to the needs of rural communities and farmers [10].

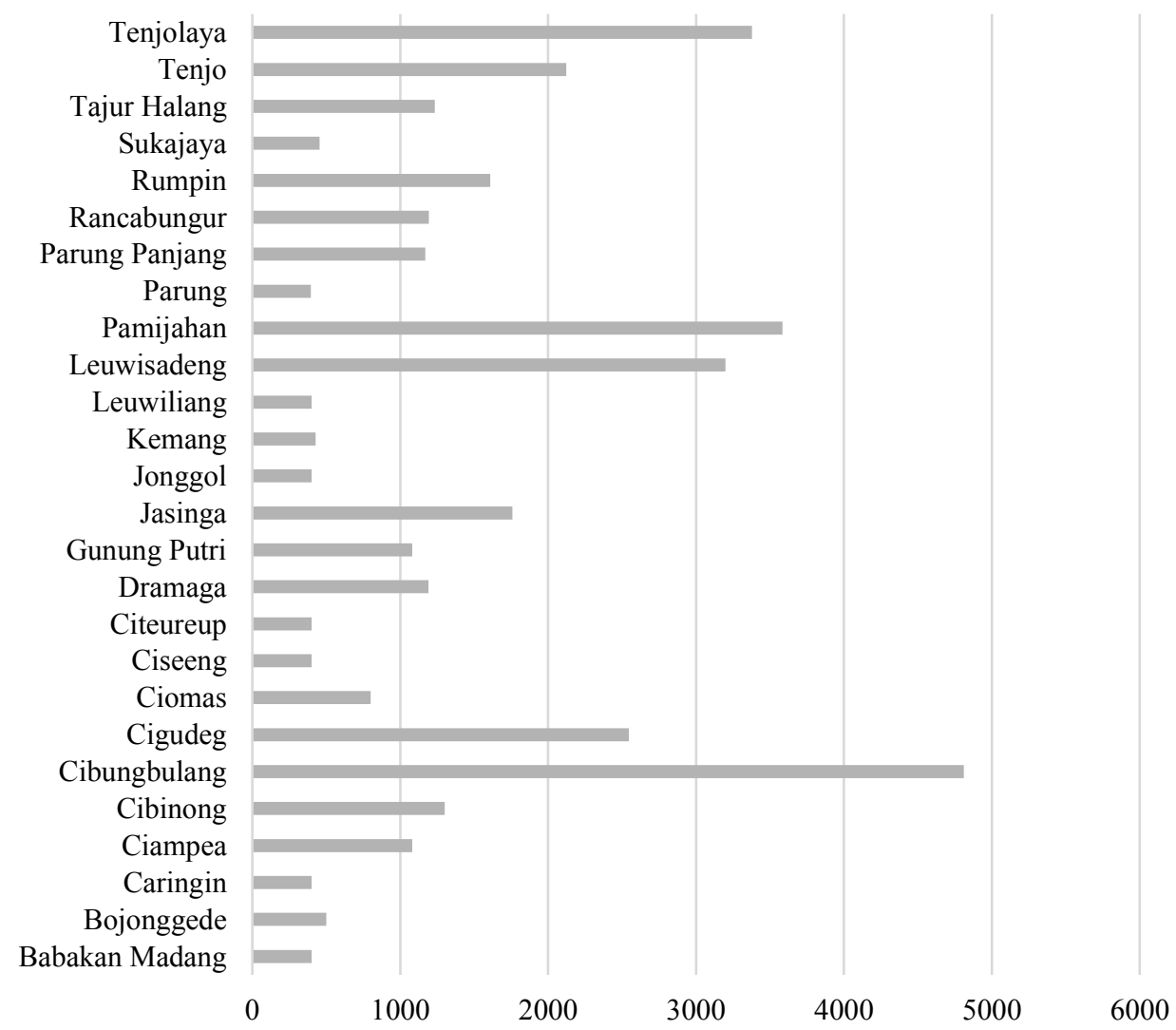

Fig. 6. The amount of distributed DOC in subdistricts of Bogor in 2020 


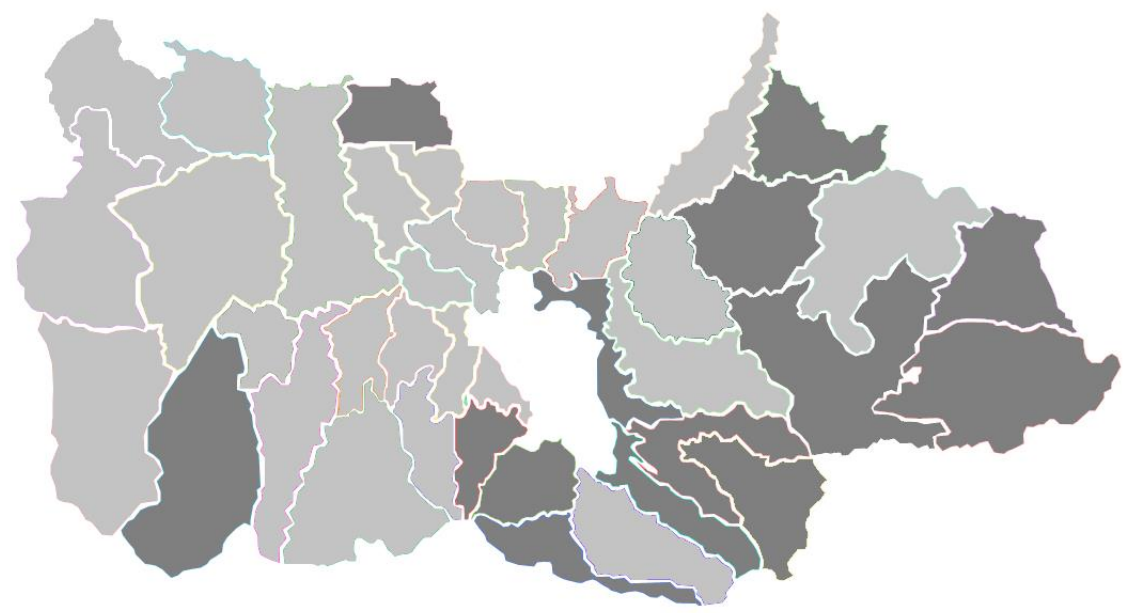

Fig. 7. The spatial distribution of DOC in 40 subdistricts of Bogor in 2020. Darker color represent the subdistricts that did not received DOC allocation

The distribution of DOC in three years dissemination program has partly adopted the Agricultural Development Zone (ADZ). For example, the subdistricts with the highest number of DOC distribution (Cibungbulang, Leuwisadeng and Pamijahan) were part of Zone 2 as an agricultural based subdistricts (Table 2). It implies that the strategy of DOC distribution was aligned with the current ADZ. Modern agriculture development needs a proper planning because it is highly dependent on many factors, including those which are related to the parameters of land spatial structure [13]. ADZ is important as a basis of agroindustry development and modernize the agricultural production to establish the areas of agro-industrial growth [14]. In addition, poultry development zone requires analysis and consideration on each agro-ecological aspect [15].

Table 2. The agricultural development zone of Bogor and its development strategies [16]

\begin{tabular}{|c|c|c|}
\hline Zones & $\begin{array}{ll}\text { Subdistricts } \\
\end{array}$ & Development strategies \\
\hline 1 & $\begin{array}{l}\text { Rumpin, Cigudeg, Parung Panjang, } \\
\text { Jasinga, Tenjo }\end{array}$ & $\begin{array}{l}\text { Agro-silvopastoral through the } \\
\text { development of agroforestry in combination } \\
\text { with agriculture and livestock }\end{array}$ \\
\hline 2 & $\begin{array}{l}\text { Sukajaya, Nanggung, Leuwiliang, } \\
\text { Leuwisadeng, Cibungbulang, Pamijahan }\end{array}$ & $\begin{array}{l}\text { Agro-ecotourism based on agriculture and } \\
\text { fishery. }\end{array}$ \\
\hline 3 & Ciampea, Tenjojaya, Dramaga, Ciomas & $\begin{array}{l}\text { Non-farm industries supported by } \\
\text { agriculture, fishery, forestry and livestock }\end{array}$ \\
\hline 4 & $\begin{array}{l}\text { Tajurhalang, Kemang, Rancabungur, } \\
\text { Parung, Ciseeng, Gunungsindur }\end{array}$ & $\begin{array}{l}\text { Rural industries and small medium } \\
\text { enterprises based on agriculture and fishery }\end{array}$ \\
\hline 5 & $\begin{array}{l}\text { Tamansari, Cijeruk, Cigombong, } \\
\text { Caringin }\end{array}$ & Agricultural diversification and ecotourism \\
\hline 6 & $\begin{array}{l}\text { Ciawi, Cisarua, Megamendung, Sukaraja, } \\
\text { Babakan Madang }\end{array}$ & $\begin{array}{l}\text { Ecotourism through collaboration with } \\
\text { private sector to provide jobs and } \\
\text { employment }\end{array}$ \\
\hline 7 & $\begin{array}{l}\text { Cileungsi, Klapanunggal, Gunung Putri, } \\
\text { Citeureup, Cibinong, Bojonggede }\end{array}$ & $\begin{array}{l}\text { Urban farming and industries based on the } \\
\text { current agriculture product and } \\
\text { commodities. }\end{array}$ \\
\hline 8 & $\begin{array}{l}\text { Sukamakmur, Cariu, Tanjungsari, } \\
\text { Jonggol }\end{array}$ & $\begin{array}{l}\text { Food estate through the improvement and } \\
\text { rehabilitation of facilities }\end{array}$ \\
\hline
\end{tabular}




\section{Conclusions}

This study showed the spatial distribution of DOC were not spread equally. This study suggests the enhancement of distribution of DOC, especially to the subdistricts in central part of Bogor and has a low population of local chicken. The Agriculture Development Zone is important as consideration in the following DOC distribution. The equal distribution based on each subdistrict's characteristics should be use a consideration to maximize the potential of DOC distribution on poverty alleviation.

\section{References}

1. C. Sumantri, I. Khaerunnisa, A. Gunawan, IOP Conf. Ser.: Earth Environ. Sci. 492 (2020)

2. C. Hidayat, S.A. Asmarasari, Jurnal Peternakan Indonesia 17, 1 (2015)

3. I.Y. Asmara, PhD Thesis, Charles Darwin University (2014)

4. I.Y. Asmara, A. Anang, T. Widjastuti, E. Sujana, Proceedings of the $2^{\text {nd }}$ International Conference on Sustainable Agriculture and Food Security: A Comprehensive Approach, KnE Life Sciences (2017)

5. H. Nurcahya, E. Sinaga, S. Darwati, I. Khaerunissa, J. Phys.: Conf. Ser. 1665 (2020)

6. Komarudin, T. Sartika, T. Kostaman, S. Sopiyana, H. Zainal, Jurnal Agripet 20, 2 (2020) [Indonesian]

7. S. Iskandar, T. Sartika, in Proceedings of the $16^{\text {th }}$ AAAP Animal Science Congress, 10-14 November 2014, Yogyakarta, Indonesia (2014)

8. Statistics Indonesia. BPS-Statistics of Bogor Regency. Bogor, Indonesia (2020)

9. O. Nicholas-Ere, International Journal of Computer Applications (0975 - 8887) 179, 7 (2017)

10. A. Cristovao, T. Koehnen, J. Portela. Food and Agriculture Organization of the United Nations (FAO), Rome (1997)

11. H.E. Samli, N. Senkoylu, H. Akyurek, A. Agma, Journal Central European Agriculture 7, 1 (2006)

12. K. Ramanathan, V. Sangeeviraman, P. Chandrahasan, B.N. Chaudhary, S.S. Ramachandra, Nature Scientific Reports 10 (2020)

13. J. Janus, A. Glowacka, P. Bozek, Engineering for Rural Development (2016)

14. E.A. Ilina, The European Proceedings of Social \& Behavioural Sciences (2018)

15. I.I. Dafwang, U. Musa, P.A. Abdu, J.U. Umoh, International Journal of Poultry Science 9 (2010)

16. Bogor Regency, Government of Bogor Regency (2017) [Indonesian] 